\title{
Banking Information Technology on Economic Inequality: An analysis of Electronic Money
}

\begin{tabular}{|c|c|}
\hline \multicolumn{2}{|r|}{ Anna Sardiana* } \\
\hline \multicolumn{2}{|c|}{ Indonesia Banking School, Jakarta, Indonesia } \\
\hline & * anna.sardiana@ibs.ac.id \\
\hline Article Info & Abstract \\
\hline Received : 2020-11-05 & The purpose of this study is to analyze and determine the role of \\
\hline Accepted : 2021-03-04 & banking technology, specifically the use of electronic money in \\
\hline Published : 2021-03-05 & reducing economic inequality in Indonesia. Gini coefficient analysis \\
\hline $\begin{array}{l}\text { Key words: economic inequality; } \\
\text { gini coefficient; banking } \\
\text { technology; electronic money }\end{array}$ & $\begin{array}{l}\text { inequality. The data used in the study was secondary data sourced } \\
\text { from the Central Statistics Agency (BPS) and Bank Indonesia (BI). } \\
\text { The comparison is done using the Gini coefficient calculation } \\
\text { method. The results of analysis in this study indicate that there is an } \\
\text { increase that causes economic inequality in Indonesia regarding the } \\
\text { use of server-based electronic money. The findings in this study also } \\
\text { indicate that chip-based electronic money which is a product of } \\
\text { banking technology can reduce the level of economic inequality in } \\
\text { Indonesia. }\end{array}$ \\
\hline
\end{tabular}

\section{INTRODUCTION}

Economic inequality in Indonesia has increased rapidly since 2000. These conditions have made economic inequality as special concern for the Indonesian government in formulating policies. The Central Statistics Agency (BPS) reported the number of poor people in September 2017 as many as 26.58 million people or 10.12 percent, the condition has decreased compared to the poor population in September 2016 as many as 27.76 million people or 10.70 percent. Based on Indonesian statistical data, the percentage of inequality of expenditure of the Indonesian population in September 2017, the level of inequality of expenditure of the Indonesian population measured by the Gini Ratio was 0.391 down from the previous year of 0.394 . Based on residence, inequality in urban areas is higher at 0.404 compared to rural inequality of 0.316 . (BPS, 2017)

Indonesia's Center of Reform on Economics (CORE) mentions that the main factor causing inequality that must be a concern of the government is labor (Budi, 2019). In August 2017, the number of unemployed was 7.04 million people and the Open Unemployment Rate (TPT) was 5.50 percent. The number decreased 0.11 points from the previous year of 5.61 percent. (BPS, 2017) There are only a few absorbed workers who can improve their skills so that they have relatively higher wages. While the rest did not receive training and lacked ability, this resulted in lower wages received and caused an income gap. According to the Central Statistics Agency the average wage of farm laborers in October 2017 was Rp50,339 per day while the average wage of construction workers was Rp84,241 per day. (BPS, 2017)

At present information technology has become an inseparable part of society. According to the Center for Innovation Policy and Governance (CIPG) research, Indonesia's internet penetration rate is the highest in Asia which has now reached $51 \%$. The history of the development of information technology in Indonesia began with the inauguration of radio in 1925. After a few decades, it was found in 1962 that television began to replace radio. The internet began to enter Indonesia in 1988, but at that time it was not widely used. In 1994, a company called IndoNet emerged. The company is recognized as the first commercial ISP 
company in Indonesia. This start became an initial milestone in the development of the Internet later in Indonesia. At the beginning of its development, the internet was used for correspondence in the work world by using an email system. But over the times, changes occur periodically. Entering the era of 2000, Indonesian people began to understand the presence of social media as a result of the existence of the internet (Abraham, 2019).

People who are increasingly literate with information technology are causing digitalization in various fields, one of which is banking. Banking technology that has been popular in Indonesia includes mobile banking, internet banking, QR code, and electronic money. According to BPS data in $201754.8 \%$ of banking transactions were conducted via the internet. Seeing this opportunity, banks in Indonesia are increasingly aggressive in improving technology-based services. (BPS, 2017). Based on the BPS data, it can be concluded that there are three main problems that must be considered in measuring the development of a country or region, namely the level of poverty, the level of unemployment, and the level of inequality in various fields. (Mudrajad, 2004). The three main problems are interrelated with one another. High levels of poverty are caused by unemployment which then impacts inequality in various fields. In other words, if one of the three things is experiencing interference then the other two things will experience the impact. In addition, poverty also arises because of the low ability of the community to access employment opportunities and the lack of community opportunities to obtain employment opportunities. The development of information technology is expected to help increase development and reduce economic inequality in a region. Therefore this study aims to analyze and determine the role of banking technology in the form of the use of electronic money in reducing economic inequality in Indonesia. This research chooses a case study of electronic money because of the various conveniences offered by electronic money when compared to other banking technologies such as mobile banking and internet banking.

\section{LITERATURE REVIEW}

Poverty can be seen from two sides, economic and social. From the economic side, poverty shows a person's inability to meet basic food and non-food needs, while from the social side shows an inability in social roles. Many factors cause poverty, both relatively fixed and developing. Relatively fixed factors such as geographical location and natural carrying capacity. While developing factors are in the form of social conditions, cultural conditions involving knowledge and skills, customs, political situations and the policies of the authorities. (Anis and Ardi, 2007).

World Bank in Sussy (2013), mentioned poverty is "The denial of choice and opportunities most basic for human development to lead a long healthy, creative life and enjoy a decent standard of living freedom, self esteem and the respect of others". Based on this definition it can be interpreted that poverty is a condition where a person cannot enjoy all kinds of choices and opportunities in meeting his basic needs such as not being able to meet health, decent living standards, freedom, self-esteem, and a sense of respect like others.

Poverty (poverty) is a problem faced by all countries, especially in developing countries like Indonesia. This is because poverty is multidimensional which means that human needs vary, so poverty can be grouped in two aspects, namely primary and secondary aspects. Primary aspects in the form of poor assets, knowledge, and skills, while secondary aspects in the form of poor social networks, financial resources, and information.

Income inequality has significant impact to poverty. Todaro (2003) states that income inequality is the difference in income generated by the community resulting in a striking difference in income within the community. (Yosi, Syamsul, and Hasdi, 2015). In other words, income inequality is the difference in the amount of community income which results in a 
greater income differential between groups in the community. As a result the rich will get richer and the poor will get poorer.

Income inequality that occurs in Indonesia can be seen based on indicators or an income inequality index, one of which is the Gini Ratio. Gini Ratio (Gini Coefficient) is a parameter used to measure the inequality of income distribution that is valued between 0 to 1 which is the ratio between the area between the Lorenz Curve and the perfect evenness line. The smaller the value of the Gini coefficient, indicating the more even distribution of income, on the contrary the greater the value of the Gini coefficient indicates an increasingly unequal distribution (there is a gap) between groups of income earners. The income inequality criteria based on the Gini Coefficient according to Todaro (2003) are: more than 0.5 is a high level of inequality; between $0.35-0.5$ is a moderate level of inequality, less than 0.35 is a low level of inequality. (Yosi, Syamsul, and Hasdi, 2015).

Greater income inequality occurs in countries that are just starting to build, whereas for developed countries or higher income levels tend to be more equitable or low levels of inequality. (Bella, Gene, and Octavian, 2018).

According to Bella, Gene, and Octavian (2018) there are 8 things that cause inequality or inequality of income distribution in developing countries:

1. High population growth resulting in a decline in income per capita.

2. Inflation in which money income increases but is not followed proportionally to the increase in product production.

3. Inequality of development between regions.

4. Very much investment in capital-intensive projects (Capital Incentive), so that the percentage of capital income from additional work is greater than the percentage of income that comes from work, so unemployment increases.

5. Low social mobility.

6. Implementation of import substitution industry policies that lead to an increase in prices of industrial products to protect the efforts of the capitalist class.

7. The deteriorating exchange rate (term of trade) for developing countries in trade with developed countries, as a result of the inelastic demand of developed countries for goods of developing countries' exports.

8. The destruction of the handicraft industry of the people such as carpentry, home industry, and others.

Levitan \& Belous (1979) argues that minimum wages can reduce inequality. The minimum wage redistributes income by reducing company profits and increasing the lowest worker wages. Thus, by setting minimum wages the wage standard will be higher and create a fairer distribution of wages and income. Cun and Khor (2010) also find that changes in the law on minimum wages are important and relevant factors contributing to slowing wage inequality between the upper and lower parts of the wage and income distribution in Indonesia. (Sari, Nazamuddin, \& Muhammad, 2015).

Panjawa and Soebagiyo (2014), Pamungkas and Suman (2017) found that the minimum wage in the business world had an impact on termination of employment which subsequently had an impact on the unemployment rate.

Iskandar Putong (2003) states that unemployed are residents who do not work but are looking for work or are preparing a new business, or residents who are not looking for work because it is impossible to find work (discouraged workers) or residents who are not looking for work because they have been hired or have a job but not yet working (future starts). Samuelson (1997) divides the causes of unemployment into 3 (three) types, namely: frictional unemployment; structural unemployment; and cyclical unemployment. In practice, Kuncoro 
(2003) classifies unemployment in several groups, namely full unemployment, half unemployed, and sometimes unemployed. (Anis and Ardi, 2007).

Finally, unemployed issue related to financial inclusion (Sheraphim, 2018). Indonesian Financial Services Authority (OJK) declared that the level of financial inclusion in Indonesia is classified as low. Ummah, Nuryartono and Anggraeni (2015) found that size of the economy and income inequality positively affect the level of financial inclusion. Opposite the research hypothesis, widening income inequality lead to higher financial inclusion in Indonesia. Moreover, the number of mobile phone and the internet user affect positively the level of financial inclusion in Indonesia. Income inequality and financial inclusion has a one-way relationship, income inequality affects financial inclusion in Indonesia but does not vice versa according to the development of information and communication technology with the increase in internet connectivity and mobile devices is driving the development of financial services infrastructure.

\section{METHODS}

The data used in the study of inequality analysis in Indonesia uses secondary data sourced from the Central Statistics Agency (BPS) and Bank Indonesia (BI). Data on the level of economic inequality, poverty, labor, and labor costs are data sourced from BPS. While data on the number of electronic money transactions and electronic money infrastructure are data sourced from BI. This research was conducted by library research. Data analysis was performed by comparing the level of inequality that occurred in Indonesia between before and after the use of electronic money by the public. The comparison is done using the Gini coefficient calculation method. Todaro (2004) says that the Gini Coefficient is a measure of aggregate inequality whose numbers range from zero (perfect equalization) to one (perfect inequality) (Westi, 2016). The Gini coefficient calculation method was introduced by Corrado Gini in 1909 in his book entitled "Concentration and dependency ratios" (in Italian). The Gini coefficient calculation model can be seen as follows:

$$
G(\text { Gini Index })=\frac{\sum_{i=1}^{N} \sum_{j=1}^{N}\left|x_{i}-x_{j}\right|}{2 \sum_{i=1}^{n} \sum_{j=1}^{n} x_{j}}
$$

Where:

$\mathrm{N}=$ number of income groups, for example $\mathrm{N}=3$, the population is divided into 3 groups, namely high, medium and low income;

$\mathrm{x}=$ share of national income of each group, for example $\mathrm{x} 1=50 \%$ means that high-income groups contribute $50 \%$ of national income.

Based on the results of these calculations, countries with a high degree of economic inequality range from 0.50 to 0.70 . Whereas for countries whose income distribution is relatively evenly distributed, the Gini Coefficient ranges from 0.20 to 0.35 . (Westi, 2016).

The criteria for aggregate inequality based on the Gini Coefficient are:
1. $\mathrm{G}<0.35$
: low inequality
2. $0.35 \leq \mathrm{G} \leq 0.5$
: moderate inequality
3. $\mathrm{G}>0.5$
: high inequality 


\section{DATA ANALYSIS AND DISCUSSION}

Bank Indonesia data noted that electronic money transactions began in 2009, however, the supporting infrastructure for electronic money (machine readers) was recorded as being used in 2013. This difference occurred because in 2009 to 2012 electronic money was server-based, while the use of electronic money was in the form of Chip-based issued by banks in Indonesia from 2013 to 2018. So the analysis of the data in this study uses data on economic inequality in Indonesia before the use of electronic money in 2008, after using server-based electronic money in 2009 to 2012, and after the use of money chip-based electronics in 2013 to 2018.

Economic inequality in Indonesia in 2008 or before the use of electronic money was 0.35 . This shows that the level of economic inequality decreased from the previous year with an imbalance level of 0.364 . In 2009 electronic money began to be used, the total transaction amounting to Rp438,669,000,000. However, at the beginning of the use of electronic money, Indonesia's economic inequality was equal to 0.37 or in other words, the level of economic imbalance rose compared to the previous year. In 2010 the number of electronic money transactions increased by Rp254,798,000,000 to Rp693,467,000,000. This is in line with the increasing level of economic inequality in the same year compared to the previous year to 0.378 .

In 2013, electronic money infrastructure began to be used, totaling 139,157 machine readers. The number of electronic money transactions also increased to Rp2,907,432,000,000 compared to the previous year of Rp1,971,550,000,000. After using the reader machine to support electronic money transactions the level of economic inequality in Indonesia decreased to 0.406 compared to the previous year with an inequality level of 0.413 .

The following is output about the Gini ratio, the number of electronic money transactions, and the number of reader machines:

Gini Ratio Comparison With Amount of Electronic Money Transactions Table

\begin{tabular}{|c|c|c|c|c|}
\hline $\begin{array}{l}\text { Sour } \\
\text { ce: } \\
\text { Seco }\end{array}$ & Year & Gini Ratio & $\begin{array}{c}\text { Amount of of Electronic Money } \\
\text { Transactions (In Millions of Rupiah) }\end{array}$ & $\begin{array}{c}\text { frastructure (Reader } \\
\text { Machines) }\end{array}$ \\
\hline ndar & 2008 & 0,35 & - & - \\
\hline $\begin{array}{l}y \\
\text { data }\end{array}$ & 2009 & 0,37 & 438.669 & - \\
\hline proc & 2010 & 0,378 & 693.467 & - \\
\hline $\begin{array}{l}\text { esse } \\
d \text {. }\end{array}$ & 2011 & 0,388 & 981.298 & - \\
\hline 2019 & 2012 & 0,413 & 1.971 .550 & - \\
\hline & $\mathrm{B}^{2013}$ & 0,406 & 2.907 .432 & 139.157 \\
\hline ase & 2014 & 0,414 & 3.319 .554 & 206.826 \\
\hline d on & 2015 & 0,402 & 5.283.017 & 281.988 \\
\hline the & 2016 & 0,394 & 7.063 .668 & 374.861 \\
\hline ysis & 2017 & 0,391 & 12.375 .468 & 691.331 \\
\hline of & 2018 & 0,384 & 47.198 .618 & 923.624 \\
\hline
\end{tabular}

these data, it can be seen that the use of electronic money in the form of chip-based products, one of the banking technology products that can cause economic inequality in Indonesia, has begun to decline in line with the increasing number of electronic money transactions and reader machines as supporting infrastructure for electronic money. This shows that banking technology in the form of chip-based electronic money also plays a role in reducing the level of inequality in Indonesia. In 2018 the level of inequality was 0.384 and at the beginning of 2019 it had decreased again to 0.382 . This shows that, the use of electronic money which is the cause of the level of inequality in Indonesia is getting closer to the category of low inequality $(<0.35)$. 
With the decreasing level of inequality in Indonesia, poverty and unemployment rates have also declined. This is because these three factors are interrelated. The number of poor people in 2013 was 28.55 million people and in 2018 the number of poor people had decreased to 25.94 million people. The unemployment rate in 2013 was $6.17 \%$ and by 2018 the budgeting rate had decreased to $5.34 \%$.

The results of this study are in line with research conducted by Ahmad (2018) who saw the role of information technology development in general in reducing inequality between regions in Indonesia. The results of these studies indicate that technological advances can make humans enjoy life more easily. But technological advances in Indonesia have not been evenly enjoyed in all parts of Indonesia. In his research, Ahmad (2018) also showed that technological progress has a positive relationship with the level of inequality. However, technological progress does not necessarily reduce the level of inequality directly because the need for supporting infrastructure and community skills in technological mastery must also be taken into account so that the maximum use of technology and the level of inequality decreases.

In line with the findings of this study, the research conducted by Fadli (2013) found that e-money services had a large role / function for the Indonesian government, namely in terms of reducing the amount of money circulating in the community. So that macro can reduce Indonesia's inflation rate. If inflation occurs continuously will cause the people's ability to obtain goods will be less or less. The level of inflation that occurs continuously with the level of economic inequality has a close relationship that is the higher the level of inflation can create or widen the level of economic inequality in a country.

In addition to this regarding the findings of this study, Hastina (2019) in her study stated that the use of non-cash payment systems using e-money had a positive and significant effect on the level of economic growth. Thus, it can be said that e-money has a positive effect on the economy in terms of reducing inequality and increasing economic growth in Indonesia.

\section{CONCLUSIONS AND SUGGESTIONS}

The conclusion from this study shows that the use of server-based electronic money actually makes economic inequality in Indonesia increase while chip-based electronic money can reduce the level of economic inequality in Indonesia. This is because only certain people are able to access or use server-based electronic money. Chip-based electronic money is more accessible to the whole community.

The policy recommendation for the government is to make a special program on the use of electronic money to the community to create a trend of less cash society that is more equitable, not concentrated in big cities. It is also hoped that the government will encourage bank business players to further develop banking technology that is easily accessible to the whole community. That way the level of economic inequality in Indonesia will be even lower.

\section{REFERENCES}

Abraham Herdyanto. (2019). Sejarah perkembangan teknologi informasi di Indonesia. IDN Times. 6 November 2019.

Ahmad Helmy Fuady. (2018). Teknologi digital dan ketimpangan ekonomi di Indonesia. Jurnal Masyarakat Indonesia, 44 (4), 75-88. 18 Oktober 2019.

Anis Setiyawati dan Ardi Hamzah. (2007). Analisis pengaruh PAD, DAU, DAK, dan belanja pembangunan terhadap pertumbuhan ekonomi, kemiskinan, dan pengangguran: pendekatan analisis jalur. Jurnal Akuntansi dan Keuangan Indonesia, 4 (2), 211-228. 7 November 2019. 
Badan Pusat Statistik (2017). Laporan bulanan data sosial ekonomi Desember 2017. 2 November 2019.

Badan Pusat Statistik (2017). Statistik telekomunikasi Indonesia 2017. 5 November 2019. Badan Pusat Statistik (2018). Laporan bulanan data sosial ekonomi Februari 2018. 2 November

2019.

Bank Indonesia (2018). Statistik sistem pembayaran infrastruktur uang elektronik 2013-2018. 7 November 2019.

Bank Indonesia (2018). Statistik sistem pembayaran transaksi uang elektronik 2009-2018. 7 November 2019.

Bella Fitria Laloan, Gene H. M. Kapantow, \& Oktavianus Porajouw. (2018). Distribusi pendapatan antar daerah di Provinsi Sulawesi Utara. Agri-Sosio Ekonomi, 14(2), 121-130. 6 November 2019.

Budi Raharjo. (2019). Atasi ketimpangan ekonomi, kebijakan harus komprehensif. Republika. 6 November 2019.

Didin Elok Parastiti, Imam Mukhlis, dan Agung Haryono. (2015). Analisis penggunaan uang elektronik pada mahasiswa fakultas ekonomi Universitas Negeri Malang (studi kasus: uang elektronik Brizzi). 7 November 2019.

Fadli M. Nur. (2013). E-money: solusi transaksi mikro modern. Jurnal Ilmu Manajemen. 13 November 2019.

Gilang Tri Pamungkas. (2018). Pengaruh perilaku konsumen terhadap penggunan e-money: studi kasus minimarket indomaret kec. Binjai kota, kota Binjai. Skripsi. Universitas Islam Negeri Sumatera Utara. 6 November 2019.

Hastina Febriaty. (2019). Pengaruh sistem pembayaran non tunai dalam era digital terhadap tingkat pertumbuhan ekonomi Indonesia. 13 November 2019.

Muhammad Ilham dan Evita Hanie Pangaribowo. (2017). Analisis ketimpangan ekonomi menurut provinsi di Indonesia tahun 2011-2015. 18 Oktober 2019.

Ummah, Bintan Badriatul, Nunung Nuryartono, Lukytawati Anggraeni (2015) ANALISIS INKLUSI KEUANGAN DAN PEMERATAAN PENDAPATAN DI INDONESIA, Jurnal

Ekonomi dan Kebijakan Pembangunan, Vol. 4 No. 1 (2015)

Panjawa, Jihad Lukis, Soebagiyo, Daryono (2014), EFEK PENINGKATAN UPAH MINIMUM TERHADAP TINGKAT PENGANGGURAN Jurnal Ekonomi dan Studi Pembangunan Volume 15, Nomor 1, April 2014, hlm.48-54

Pemerintah Indonesia. 2013. Undang-Undang No.13 Tahun 2003 Tenaga Kerja bab I pasal 1 ayat 30. Lembaran Negara RI Tahun 2013, No. 13. Sekretariat Negara. Jakarta. 7 November 2019.

Pemerintah Indonesia. 2018. Peraturan Menteri No. 15 Tahun 2018 Pasal 1 ayat 1 tentang Upah Minimum. Lembaran Negara RI Tahun 2018, No. 15. Sekretariat Negara. Jakarta. 7 November 2019. 
Pemerintah Indonesia. 2009. Peraturan Bank Indonesia No.11/12/PBI/2009 tentang Uang Elektronik (Electronic Money). Lembaran Negara RI Tahun 2009, No. 11. Sekretariat Negara. Jakarta. 8 November 2019.

Prawidya Hariani RS dan Aulia Rizky Syahputri. (n.d.). Analisis ketimpangan ekonomi dan pengaruhnya terhadap tingkat kriminalitas di propinsi Sumatera Utara. . 8 November 2019.

Sari Nurmalisa Sungkar, Nazamuddin, \& Muhammad Nasir. (2015). Pengaruh upah minimum terhadap ketimpangan pendapatan di Indonesia. Jurnal Ilmu Ekonomi, 3 (2), 40-53. 6 November 2019.

Sheraphim, Graciela Kristia (2017), Pengaruh Tingkat Inklusi Keuangan, Tingkat Pengangguran Terbuka (TPT), Dana Pihak Ketiga (DPK) Dan Penanaman Modal Dalam Negeri (PMDN) Terhadap Tingkat Pertumbuhan Ekonomi Di 33 Provinsi Indonesia Periode 2011-2016, Jurnal Ilmiah Mahasiswa Fakultas Ekonomi dan Bisnis, Vol 6, No 2, 2017

Sussy Susanti. (2013). Pengaruh produk domestik regional bruto, pengangguran dan indeks pembangunan manusia terhadap kemiskinan di Jawa Barat dengan menggunakan analisis data panel. Jurnal Matematika Integratif , 9 (1), 1-18. 6 November 2019.

Westi Riani. (2016). Keterbatasan indeks gini sebagai ukuran ketimpangan pendapatan dan solusi metoda alternatif. Prosiding Seminar Nasional Penelitian dan PKM Sosial, Ekonomi dan Humaniora, 6 (1), 708-715. 6 November 2019.

Yenny Tjoe. (2018). Seberapa parah ketimpangan ekonomi di Indonesia?. Kompas. 6 November 2019.

Yosi Eka Putri, Syamsul Amar, \& Hasdi Aimon. (2015). Analisis faktor-faktor yang mempengaruhi pertumbuhan ekonomi dan ketimpangan pendapatan di Indonesia. Jurnal Kajian Ekonomi, 3(6). 7 November 2019. 